\title{
(JIPD)
}

Jurnal Inovasi Pendidikan Dasar

Vol. 4, No. 1, Bulan Januari Tahun 2020, Hal. 1-5

E-ISSN: 2598-408X, P-ISSN: 2541-0202

http://unikastpaulus.ac.id/jurnal/index.php/jipd

\section{PAKEM BERBASIS SISTEM PERILAKU DALAM PENINGKATAN MOTIVASI BELAJAR SISWA SEKOLAH DASAR}

\author{
Reza Syehma Bahtiar \\ Prodi PGSD Universitas Wijaya Kusuma Surabaya \\ Jl. Dk Kupang XXV/54 Surabaya \\ email: syehma@gmail.com
}

Diterima: 11 Januari 2020, Direvisi: 15 Januari 2020, Diterbitkan: 31 Januari 2020

\begin{abstract}
This study aims to determine the success in increasing student motivation to learn PAKEM based on behavioural systems. This research is a type of qualitative research conducted at SDN Jajartunggal III Surabaya class I as many as 24 students. As for the research instrument, the observation sheet / observation sheet and the test sheet. In this study, the average results of completeness of the thinking skills test showed that of 24 students in grade 1 at SDN Jajartunggal III Surabaya, reaching 87.5\%. These results have exceeded the percentage of assessment indicators $85 \%$ of all students. The results of the analysis of the discussion about the results of highlevel essential thinking skills test (C3 - C6) for students during the learning process obtained that the first grade students of SDN Jajartunggal III Surabaya during the study reached a value of $87.5 \%$ of all students. The results of students' learning motivation obtained during the essential thinking skills test were $91.68 \%$. This percentage has exceeded the percentage of research indicators $85 \%$ of all students who scored $\geq 75$.
\end{abstract}

Keywords: pakem, behavioral system, learning motivation

\begin{abstract}
Abstrak. Penelitian ini bertujuan untuk mengetahui keberhasilan dalam meningkatkan motivasi belajar siswa dengan pembelajaran PAKEM berbasis sistem perilaku. Penelitian ini adalah jenis penelitian kualitatif yang dilaksanakan di SDN Jajartunggal III Surabaya kelas I sebanyak 24 siswa. Sedangkan untuk instrument penelitiannya adalah lembar observasi/pengamatan dan lembar tes. Pada penelitian ini, hasil rata - rata ketuntasan tes keterampilan berpikir menunjukkan dari 24 siswa kelas I SDN Jajartunggal III Surabaya mencapai hasil $87,5 \%$. Hasil tersebut sudah melampaui persentase indikator penilaian $85 \%$ dari keseluruhan siswa. Hasil analisis pembahasan mengenai kaberhasilan tes keterampilan berpikir esensial tingkat tinggi (C3 C6) siswa selama proses pembelajaran diperoleh bahwa siswa kelas I SDN Jajartunggal III Surabaya selama penelitian mencapai nilai $87,5 \%$ dari keseluruhan siswa. Hasil motivasi belajar siswa yang diperoleh pada saat tes keterampilan berpikir esensial adalah sebesar 91,68\%. Persentase tersebut sudah melampaui persentase indikator penelitian $85 \%$ dari keseluruhan siswa yang mendapat nilai $\geq 75$.
\end{abstract}

Kata Kunci: pakem, sistem perilaku, motivasi belajar.

\section{PENDAHULUAN}

Dewasa ini profesionalitas seorang guru sangat dibutuhkan di setiap pembelajaran yang diberikan. Metode - metode pembelajaran yang konvensional sudah banyak ditinggalkan karena dianggap kurang memberikan perubahan yang memuaskan terhadap motivasi belajar siswa. Dari keinginan para guru untuk merubah paradigma pembelajaran dari metode konvensional menuju ke pembelajaran yang inovatif, muncul beberapa model dan metode yang dianggap mampu memberikan inovasiinovasi dalam pembelajaran. Salah satunya adalah pembelajaran yang bernuansa PAKEM. Dilihat dari namanya, PAKEM (Pembelajaran Aktif Kreatif Efektif dan Menyenangkan) tentunya mampu memberikan nuansa pembelajaran yang menarik dan tidak membosankan sehingga dapat meningkatkan kemampuan berpikir siswa. PAKEMadalah proses pembelajaran dimana guru sangat berperan dalam menciptakan suasana pembelajaran yang dapat mengaktifkan siswa 
dengan menerapkan berbagai kegiatan pembelajaran yang dapat mengembangkan keterampilan, sikap dan kepahaman(Hayati \& Lailatussaadah, 2016). Kemudian (Nurdin, 2015) mengutarakan PAKEM dimaksudkan bahwa dalam proses pembelajaran guru harusmenciptakan suasana sedemikian rupa sehingga siswa aktif bertanya mempertanyakan dan mengemukakan gagasan. Sedangkan Sealnjutnya Asmani menambahkan PAKEM (pembelajaran yang aktif, kreatif, efektif dan menyenangkan). Aktif

dimaksudkan bahwa dalam proses pembelajaran, guru harus menciptakan suasana sedemikian rupa, sehingga siswa aktif bertanya, mempertanyakan dan mengemukakan gagasan. Kreatif juga dimaksudkan agar guru menciptakan kegiatan belajar yang beragam, sehingga memenuhi berbagai tingkat kemampuan membaca permulaan siswa. Kekreatifitasan bisa terlihat dari beragamnya alat dan bahan pembelajaran yang dibuat untuk menunjang efek menyenangkan pada siswa. Efektif berarti proses pembelajaran tersebut bermakna bagi siswa. Selain itu, sejumlah tujuan pembelajaran yang ditetapkan harus tercapai. Menyenangkan maksudnya adalah membuat suasana belajar mengajar yang menyenagkan, sehingga siswa memusatkan perhatiannya secara penuh pada belajar dan waktu curah anak pada pelajaran menjadi (time on task) atau dengan kata lain keterlibatan dan fokus anak penuh pada kegiatan pembelajaran mulai dari awal hingga akhir(Mayangsari, 2014). Dengan demikian istilah PAKEM merupakan sebuah proses pembelajaran yang bersifat aktif, kreatif, dan menyenangkan yang dibuat guru untuk meningkatkan kemampuan siswa baik dari segi kognitif,, psikomotor, maupun afektif.

SDN Jajatunggal III Surabaya, adalah salah satu sekolah yang selalu melakukan inovasi - inovasi dalam pembelajarannya. Salah satunya adalah menerapkan pembelajaran bernuansa PAKEM. Pada siswa kelas I, pembelajaran PAKEM juga diberikan dengan tujuan dapat meningkatkan motivasi belajar siswanya. Hal tersebut dianggap berhasil karena menurut gurunya, nilai siswa pada mata pelajaran IPS sudah dapat mencapai KKM (Kriteria Ketuntasan Minimal) di sekolah. Namun ketika ditanya bagaimana guru tersebut membelajarkan PAKEM, jawabannya adalah sudah melakukan pembelajaran secara kelompok (kooperatif), menyediakan taman baca, dan mengumpulkan hasil karya siswa. Namun ternyata hasil karya siswa yang dimaksudkan adalah yang berupa LKS dan hasil jawaban dari pertanyaan pertanyaan konseptual yang ada dalam LKS.

Berdasarkan permasalahan tersebut, peneliti ingin mencari sumber permasalahan yang menyebabkan siswa tidak memiliki motivasi belajar yang tinggi. Jika ditelusuri dari latar belakang siswa SDN Jajartunggal III Surabaya, kondisi sosial ekonomi dan pendidikan orang tua siswa cukup memadai. Untuk itu peneliti terfokus pada guru yang telah memberikan pembelajaran bernuansa PAKEM pada siswa kelas I.

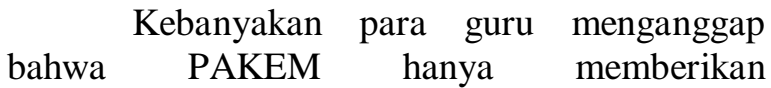
pembelajaran dengan menyanyi pada saat apersepsi ataupun dengan merubah tatanan tempat duduk saatberkelompok. Padahal pembelajaran yang bernuansa PAKEM juga menekankan siswa untuk memiliki kemampuan berpikir dalam memecahkan suatu masalah dengan menyenangkan yang berakibat meningkatnya motivasi belajar siswa. Untuk itu pada pembelajaran yang diterapkan di kelas I ini peneliti menghipotesiskan sesuai dengan tingkat perkembangannya adalah PAKEM yang berbasis sistem perilaku, mengingat siswa kelas I masih membutuhkan pengarahan secara langsung dan pemodelan.

Pada saat ini pentingnya memiliki motivasi belajar yang tinggi, khususnya pada siswa $\mathrm{SD}$, telah menjadi isu sentral dalam sistem pendidikan Indonesia. Di dalam Standar Isi (Permendiknas nomor 22 tahun 2006) dinyatakan bahwa pembelajaran IPS sebaiknya dilaksanakan secara inkuiri ilmiah (scientific inquiry) untuk menumbuhkan kemampuan berpikir, bekerja dan bersikap ilmiah serta mengkomunikasikannya sebagai aspek penting kecakapan hidup. Di dalam Standar Isi dinyatakan pula bahwa mata pelajaran IPS di SD/MI bertujuan agar peserta didik memiliki keterampilan mengembangkan keterampilan proses untuk menyelidiki alam sekitar, memecahkan masalah, dan membuat keputusan. Sedangkan di dalam Standar Proses (Permendiknas nomor 41 tahun 2007), secara eksplisit dinyatakan bahwa di dalam pelaksanaan pembelajaran, guru memberikan kesempatan siswa untuk berpikir, menganalisis, menyelesaikan masalah, dan bertindak tanpa rasa takut. Kutipan-kutipan tersebut memperlihatkan pentingnya keterampilan berpikir yang mampu membangkitan motivasi belajar, baik tingkat dasar maupun tingkat tinggi, dan menjadi standar proses dalam pembelajaran dan menjadi salah 
satu tujuan pembelajaran IPS di tingkat SD, termasuk SDN Jajartunggal III Surabaya.

Penelitian tentang PAKEM untuk meningkatkan motivasi belajar akan berhulu pada garis besar gambaran pelaksanaan PAKEM. Berdasarkan buku panduan pelaksanaan PAKEM yang dikeluarkan oleh(Depdiknas, 2010), secara garis besar gambaran PAKEM adalah: belajar melalui berbuat, penggunaan berbagai alat bantu pembelajaran, menyediakan "pojok baca", penerapan kooperatif dan interaktif, serta mendorong siswa untuk menemukan pemecahan masalah dan pengungkapan gagasan. Garis besar gambaran PAKEM tersebut menunjukkan kata kunci pelaksanaan PAKEM untuk melatihkan keterampilan berpikir yang relevan dengan model pembelajaran dan mampu mambangkitkan motivasi belajar siswa. Salah satunya yakni pembelajaran yang berbasis sistem perilaku (misalnya berpikir induktif, penemuan konsep, dan penelitian ilmiah). Model pembelajaran berbasis sistem perilaku tersebut, dengan ditambahkan kata kunci "menyenangkan", dijadikan dasar bagi pembelajaran PAKEM IPS yang digunakan untuk meningkatkan keterampilan berpikir esensial siswa kelas I SDN Jajartunggal III Surabaya. Pemilihan kelas I tersebut sesuai dengan temuan dari diskusi terfokus Masalah yang dihadapi kelas I tersebut berkaitan dengan kurangnya penguasaan keterampilan berpikir esensial adalah serupa.

Pembelajaran langsung banyak diilhami oleh teori belajar sosial yang juga sering disebut belajar melalui observasi. Dolard, Miller dan Bandura mempercayai sebagian besar manusia belajar melalui pengamatan secara selektif dan mengingat tingkah laku orang lain(Suryanti, 2009). Pemikiran mendasar dari model pembelajaran langsung adalah bahwa siswa belajar dengan mengamati secara selektif, mengingat dan menirukan tingkah laku gurunya. Pada pembelajaran langsung, terdapat dua hal penting yang harus dilakukan yaitu (1) menyampaikan pengetahuan secara sederhana, (2) demonstrasi dan bimbingan dalam menyampaikan pengetahuan harus dilakukan secara berulang - ulang.

Maka pada siswa kelas I akan diberikan pembelajaran PAKEM berbasis sistem perilaku yang terdapat pada pembelajaran langsung, mengingat siswa kelas I SD masih membutuhkan contoh - contoh perilaku yang positif dari gurunya untuk melatih dan mengembangkan keterampilan berpikir aplikasi, analisis, evaluasi, dan keterampilan mencipta mereka.
Dengan diberikan pembelajaran PAKEM berbasis sistem perilaku yang terdapat pada pembelajaran langsung, siswa kelas I dapat meningkatkan motivasi belajar secara maksimal.

\section{METODE PENELITIAN}

Penelitian ini adalah jenis penelitian kualitatif yang dilaksanakan di SDN Jajartunggal III Surabaya kelas I sebanyak 24 siswa. Pada tahap perencanaan, kegiatan yang akan dilakukan pada penelitian ini adalah menyusun Rancangan Pembelajaran dengan menggunakan PAKEM yang berbasiskan sistem perilaku, menyusun Lembar Pengamatan untuk mengetahui bagaimana motivasi belajar siswa setelah pembelajaran dengan PAKEM, kemudian membuat Lembar Penilaian Kinerja. Setelah kegiatan perencanaan selesai tahap berikutnya adalah melakukan implementasi sesuai dengan langkah-langkah pembelajaran yang disusun dalam Rencana Pembelajaran.

Selama melakukan penelitian, dilakukan observasi oleh peneliti tentang oleh aktivitas siswa dengan menggunakan Lembar Pengamatan untuk mengetahui tingkat motivasi belajar siswa. Tes hasil belajar digunakan sebagai pelengkap untuk mengevaluasi motivasi belajar siswa yang ditumbuhkan melalui aktivitas pembelajaran.

Setelah semua data terkumpul dan dianalisis selanjutnya dilakukan diskusi antara peneliti dan guru (peneliti mitra) untuk mendiskusikan bagaimana pelaksanaan pembelajaran, hambatan-hambatan yang muncul serta bagaimana motivasi belajar siswa. Data yang telah dikumpulkan dalam penelitian ini selanjutnya dilakukan analisis secara deskriptif kualitatif.

\section{HASIL DAN PEMBAHASAN}

Pada tahap perencanaan terdapat empat pertemuan yang didalamnya mempelajari dua kompetensi dasar dan media yang digunakan adalah media gambar dan benda - benda konkret. Evaluasi pada proses pembelajaran dilakukan pada saat penilain saat berdiskusi kelompok. Sementara evaluasi individu dilakukan di akhir pembelajaran pada pertemuan ke -8 . Pada tahap pelaksanaan dilakukan sebanyak empat pertemuan yaitu pertemuan V, VI, VII, dan VIII. Pada pertemuan $\mathrm{V}$ pembelajaran terencana dalam RPP Fokus penelitian ini adalah ketuntasan motivasi belajar siswa yang dalam pembelajaran masih belum tercapai. Beberapa kelebihan dalam pembelajaran ini sangat membantu dalam 
menentukan hasil pencapaian belajar siswa. Lebih lanjut akan disajikan beberapa kelemahan dan kelebihan dalam tabel 1 .

Tabel 1. Catatan Hasil Pengamatan

\begin{tabular}{|c|c|}
\hline Kelebihan & Kelemahan \\
\hline $\begin{array}{ll}\text { 1. } & \text { Siswa sangat } \\
\text { antusias dalam } \\
\text { mengikuti }\end{array}$ & $\begin{array}{ll}1 . & \text { Beberapa } \\
\text { siswa } \\
\text { masih } \\
\text { pasif }\end{array}$ \\
\hline
\end{tabular}

Dari hasil observasi di atas tampak bahwa kelemahan sudah semakin bisa diatasi. Namun masih ada satu kelemahan yaitu masih ada siswa yang pasif pada saat kerja sama dalam kelompok. Namun hal tersebut sudah dapat langsung diatasi oleh guru.Hasil observasi pada tiap data yang dikumpulkan adalah sebagai berikut.

Tabel 2. Hasil Analisis Data

\begin{tabular}{|c|c|c|c|}
\hline No & Jenis data & $\begin{array}{l}\text { Hasil } \\
\text { Analisis }\end{array}$ & Ketercapaian \\
\hline 1 & $\begin{array}{l}\text { Data kualitas } \\
\text { pembelajaran } \\
\text { guru }\end{array}$ & $84,12 \%$ & Tercapai \\
\hline 2 & $\begin{array}{l}\text { Data Aktivitas } \\
\text { siswa } \\
\text { Respon siswa }\end{array}$ & $\begin{array}{l}82,49 \% \\
\text { Rata - rata } \\
>\quad 85 \% \\
\text { sangat } \\
\text { senang }\end{array}$ & $\begin{array}{l}\text { Tercapai } \\
\text { Tercapai }\end{array}$ \\
\hline 3 & $\begin{array}{lr}\begin{array}{l}\text { Aspek } \\
\text { (aplikasi) }\end{array} & \text { C3 } \\
\begin{array}{l}\text { Aspek } \\
\text { (analisis) }\end{array} & \text { C4 } \\
\begin{array}{l}\text { Aspek } \\
\text { (evaluasi) }\end{array} & \text { C5 } \\
\begin{array}{l}\text { Aspek } \\
\text { (mencipta karya) }\end{array} & \text { C6 }\end{array}$ & $\begin{array}{l}87,8 \% \\
86,04 \% \\
88,65 \% \\
87 \%\end{array}$ & $\begin{array}{l}\text { Tercapai } \\
\text { Tercapai } \\
\text { Tercapai } \\
\text { Tercapai }\end{array}$ \\
\hline
\end{tabular}

Dari tabel 2 tersebut dapat kita ketahui

bahwa semua aspek mulai dari kualitas pembelajaran yang dilakukan guru, aktivitas dan respon siswa, juga aspek keterampilan berpikirnya mulai dari C3 hingga C6 sudah tercapai. Berdasarkan hasil tersebut motivasi belajar siswa dapat meningkat melalui PAKEM berbasis sistem perilaku.
Pembahasan pada penelitian ini meliputi tiga aspek yaitu bagaimana hasil keterampilan berpikir esensial tingkat tinggi sekaligus menjadi hasil motivasi siswa yang dipengaruhi oleh aktivitas guru dan siswa selama pembelajaran. Dan jika dari ketiga aspek tersebut terdapat peningkatkan nilai yang signifikan, maka penelitian ini dikategorikan berhasil. Ketercapaian keterampilan berpikir sesuai pada rencana penelitian yaitu hasil ketuntasan tes keterampilan berpikir mencapai 75 . Pada penelitian ini, hasil rata - rata ketuntasan tes keterampilan berpikir menunjukkan dari 24 siswa kelas I SDN Jajartunggal III Surabaya mencapai hasil $87,5 \%$. Hasil tersebut sudah melampaui persentase indikator penilaian $85 \%$ dari keseluruhan siswa.

Hasil analisis pembahasan mengenai kaberhasilan tes keterampilan berpikir esensial tingkat tinggi (C3 - C6) siswa selama proses pembelajaran diperoleh bahwa siswa kelas I SDN Jajartunggal III Surabaya selama penelitian mencapai nilai $87,5 \%$ dari keseluruhan siswa. Hasil motivasi belajar siswa yang diperoleh pada saat tes keterampilan berpikir esensial adalah sebesar 91,68\%. Persentase tersebut sudah melampaui persentase indikator penelitian $85 \%$ dari keseluruhan siswa yang mendapat nilai $\geq 75$. Secara garis besar dapat disimpulkan bahwa penelitian ini menunjukkan keberhasilan dalam meningkatkan motivasi belajar siswa dengan pembelajaran PAKEM berbasis sistem perilaku.

\section{KESIMPULAN}

Penelitian ini fokus pada penerapan PAKEM berbasis sistem - sistem perilaku dalam pembelajaran IPS yang berhasil meningkatkan motivasi siswa kelas I SDN Jajartunggal III Surabaya dengan indikasi ketercapaian keterampilan berpikir sesuai pada rencana penelitian yaitu hasil ketuntasan tes keterampilan berpikir mencapai 75. Pada penelitian ini, hasil rata - rata ketuntasan tes keterampilan berpikir menunjukkan dari 24 siswa kelas I SDN Jajartunggal III Surabaya mencapai hasil 87,5\% . Hasil tersebut sudah melampaui persentase indikator penilaian $85 \%$ dari keseluruhan siswa. Hasil analisis pembahasan mengenai kaberhasilan tes keterampilan berpikir esensial tingkat tinggi (C3 - C6) siswa selama proses pembelajaran diperoleh bahwa siswa kelas I SDN Jajartunggal III Surabaya selama penelitian mencapai nilai $87,5 \%$ dari keseluruhan siswa. Hasil motivasi belajar siswa yang diperoleh pada 
saat tes keterampilan berpikir esensial adalah sebesar 91,68\%. Persentase tersebut sudah melampaui persentase indikator penelitian $85 \%$ dari keseluruhan siswa yang mendapat nilai $\geq 75$. Secara garis besar dapat disimpulkan bahwa penelitian ini menunjukkan keberhasilan dalam meningkatkan motivasi belajar siswa dengan pembelajaran PAKEM berbasis sistem - sistem perilaku. Berdasarkan hel tersebut, secara garis besar dapat disimpulkan bahwa penelitian ini menunjukkan keberhasilan dalam meningkatkan motivasi belajar siswa dengan pembelajaran PAKEM berbasis sistem perilaku.

\section{DAFTAR RUJUKAN}

Depdiknas. (2010). Taksonomi Tujuan Pendidikan Menurut Bloom. http://www.mgpbe.depdiknas.go.id/cms/upload/publikasi/m 01u01b.pdf)

Hayati, S., \& Lailatussaadah, L. (2016). Validitas Dan Reliabilitas Instrumen Pengetahuan Pembelajaran Aktif, Kreatif Dan Menyenangkan (Pakem) Menggunakan Model Rasch. Jurnal Ilmiah Didaktika, 16(2), 169. https://doi.org/10.22373/jid.v16i2.593

Mayangsari, D. (2014). Peningkatan Kemampuan Membaca Permulaan Kelas 1 Sd Mardi Putera Surabaya Dengan Menggunakan Pakem (Pembelajaran Yang Aktif, Kreatif, Efektif, Dan Menyenangkan). Modeling Jurnal Prgogram Studi PGMI, 1(1), 62-69. http://jurnal.stitnualhikmah.ac.id/index.php/ modeling/article/view/35

Nurdin, S. (2015). Penerapan Pendekatan PAKEM dalam Pembelajaran IPA DI MIN Rukoh. PIONIR Junal Pendidikan, 4(2), 111. https://doi.org/10.1017/CBO978110741532 4.004

Suryanti. (2009). Model - Model Pembelajaran Inovatif. Unesa University Press. 